\title{
FAMILY PERCEPTION IN READINESS ACCEPTING DISCHARGE PLANNING DETERMINED BY NURSING ADVOCACY PROGRAM
}

\author{
Mohamad Judha ${ }^{1 *}$ \\ ${ }^{1}$ Universitas Respati Yogyakarta \\ Email*: judha.fikesunriyo@gmail.com
}

\begin{abstract}
Introduction: Planning for patients to go home raises the issue of whether the patient is ready to face health problems at home, the lack of a support system becomes a problem especially if the patient as the head of the family needs continuity of care both in the healing process and in maintaining the patient's health status both at home sick or at home. The purpose of this study was to determine how is the Role of Advocacy given by Nurses with Readiness in Receiving Discharge Planning by patients and families. Methods: The cross-sectional correlational study in this study views the patient's family support in readiness to receive the patient's home program on the ward. Sampling 97 respondents with a purposive sample technique. Results: Family perceptions about nurses in the positive category (73.2\%). The level of family readiness in accepting return planning in the good category (53.6\%), the results of the bivariate analysis using the Spearman rating relate to family perceptions about nurse advocacy with readiness in accepting return planning with a p value of $0.00<$ alpha 0.01. Conclusion: Family perceptions about nurse advocacy with home preparation have a strong relationship, so family assistance in nursing care in re-care planning is needed. family perceptions of nurses are needed including nursing actions or other matters relating to care by the family also need to support patient health.
\end{abstract}

Keywords: discharge planning; family; nurses; patients

\section{INTRODUCTION}

The characteristic of a professional nurse is having an attitude of taking responsibility for meeting the client's basic needs and being expected to be able to view the client as a unique, holistic and comprehensive being. From this holistic basis a nurse understands the individual in a long range of healthy-sick concepts. Nurses must view individuals as whole beings that have complex basic needs, interrelated with one another's needs(Notoatmojo, 2003). When family perceptions about nurse advocacy and actions of nursing care in the planning of patient care home are not done, then the patient does not get guaranteed program support from people around him so that there is a possibility of patients when at home will get sick again. Nursing care is also given comprehensively which means that in meeting the basic needs of the client, the nurse does not only focus on meeting physical or psychological needs, but all aspects are the responsibility of a nurse. Nurses' activities are carried out in a promotive, preventive, curative, and rehabilitative effort with an emphasis on primary health care to enable everyone to achieve the ability to live healthy and productive lives (Gaffar, 2014).

As a care giver, nurses help clients regain their health through a process of healing that is more than just recovering from certain diseases but focuses on client health compliance holistically, including efforts to restore emotional, spiritual, and social health. Before taking nursing actions, both in assessing the client's condition, providing care and evaluating results, the nurse prepares an action plan by determining the best approach for each client ${ }^{14}$. This determination is done alone by the nurse or can collaborate with the client's family and in such circumstances the nurse can also work together and consult with other health professionals (Keeling, A.W. dan Ramos, M.C. (2008). 
The family has a very important role in the patient's healing process, because the family is the closest support system for patients. The family must always be involved in planning, nursing, and treating patients, preparing for the patient's discharge and home follow-up plans. most families don't know how to take care, what causes illness and how to maintain good health. If you know the Family knows these three things will be motivated and participate actively in efforts to solve the patient's problem (Suliswati, 2005).

Discharge planning as a process of preparing patients to leave one service unit to another unit inside or outside a public health service agent. Discharge planning is known as discharge planning which is a process where the patient begins to get health care followed by continuity of care both in the healing process and in maintaining his health status until the patient feels ready to return to his environmen (Nursalam, 2002).

In Indonesia, nursing services have designed various forms of patient discharge planning formats, but most are used only in the form of documenting resume patients returning home, in the form of information that must be delivered to patients going home, such as medical and non-medical interventions that have been given, control schedules, nutrition must be fulfilled after at home (Judha, 2017). This method is providing information targeted to patients and families just to know and remind, but no one can guarantee whether the patient and family know what risk factors can make the disease recur, what treatment can be done emergencies against the condition of the disease (Judha, 2016).

The role of the nurse is very important in preparing the return of the patient and family in the provision of discharge planning or discharge planning by paying attention to the patient's problems and the care they need ${ }^{15}$. By teaching patients and family members in the provision of client care that will be done at home (Ester, 2005).

According to data obtained from the Medical Records section of Bantul district in November 2016, data on the number of patients from January to December 2015 reached 23,926 patients from various wards. While from January to September 2016 reached 20,509 patients from various wards. The majority of inpatient cases are Asphyxia as many as 1,505 cases, Primary hypertension as many as 943 cases, Diarrhea and Gastroenteritis as many as 908 cases, Caesarean section as many as 846 cases, Neonatal Jaundice as many as 752 cases.

From interviews with 20 families of patients treated at Bantul Hospital, most of the data were obtained, namely 14 families did not know about discharge planning and several families did not know what to prepare and do in receiving discharge planning. It can be explained that the results of interviews with several families of patients obtained the majority of results have not been able to answer correctly related to the questions given about discharge planning. Family perceptions of nurses in special nursing care in preparation. Based on the published background, the researchers are interested in conducting research on "Family relationships about nurses with readiness to receive discharge plans". The purpose of this study was to determine the relationship of family perceptions about the readiness to accept the patient's home program.

\section{METHODS}

This research is a correlation study, with cross-sectional design. This research was conducted in several wards in Bantul district hospital. The population in this study were all families of patients who guarded their sick families in the Bantul Regency wardThe sample in the study of 97 people was determined based on the method of sampling with incidental purposive sampling technique. Inclusion criteria 
are the age of the patient 21-59 years, the minimum level of education of junior high school, there is a blood relationship with the patient, one patient is represented by one family, the minimum patient waiting is 8 hours, the patient is responsible, wants to be a respondent.

The independent variable in this study is the family's perception of nurses. The dependent variable is readiness to accept discharge planning. The tool used for primary data collection in this study was a questionnaire. The research questionnaire is a modification of several studies on family support and the theory of J Watson (2003) about caring. The type of statement used in the form of a closed statement consisting of 18 questions to explore information on the perception of families about nurses who have tested the validity and 10 items to assess the level of readiness to accept discharge planning. The scale used is the Gutman scale where the research subjects were asked to give or answer one statement with 2 response categories namely score 2 for YES answers and score 1 for NO answers. In the family perception variable about nurses the research results are categorized into 2 categories. Positive if the answer score is correct 27-36, negative if the answer score is true 18-26.

On the readiness variable in receiving discharge planning The indicators used are good if the score is 17-20, Sufficient (if score 14-16, lacking (if score 10-13) Secondary data in this study are the number of patients treated in January 2015-October 2016 and 5 major cases of disease.The data processing technique is divided into 4 stages, namely editing, coding, entry, and cleening then proceed with univariate analysis using frequency distribution and bivariate analysis with Spearman rank correlation, statistical test to test 2 variables that have ordinal data or one variable with ordinal data and the other nominal or ratio.

This study was conducted through an ethical test from the education ethics commission in and from the hospital where the study was conducted. The results of the ethics prove that there is no need to oppose ethics that are violated.

\section{RESULTS}

\section{a. Univariat}

\section{1) Demographic data}

Demographic data of the study sample taken from gender, age, occupation and education.

Table 1.Characteristics of Respondent $(n=97)$

\begin{tabular}{|c|c|c|}
\hline Variabel & Frek (n) & $(\%)$ \\
\hline \multicolumn{3}{|l|}{ Gender } \\
\hline Man & 38 & 39,2 \\
\hline women & 59 & 60,8 \\
\hline Total & 97 & 100,0 \\
\hline \multicolumn{3}{|l|}{ Age } \\
\hline $21-39$ & 38 & 39,2 \\
\hline $40-59$ & 59 & 60,8 \\
\hline Total & 97 & 100,0 \\
\hline \multicolumn{3}{|c|}{ Level of education } \\
\hline Junior & 55 & 56,7 \\
\hline senior & 33 & 34,0 \\
\hline Diploma & 3 & 3,1 \\
\hline Bachelor & 6 & 6,2 \\
\hline Total & 97 & 100,0 \\
\hline \multicolumn{3}{|l|}{ Work } \\
\hline \multirow{2}{*}{$\begin{array}{l}\text { Housewife } \\
\text { farmer }\end{array}$} & 26 & 26,8 \\
\hline & 44 & 45,4 \\
\hline & 4 & 4,1 \\
\hline $\begin{array}{l}\text { gov employee } \\
\text { entepreneur }\end{array}$ & 23 & 23,7 \\
\hline Total & 97 & 100 \\
\hline \multicolumn{3}{|c|}{ Status of relation with patients } \\
\hline Child & 38 & 39,2 \\
\hline father & 25 & 25,8 \\
\hline mother & 34 & 35,1 \\
\hline Total & 97 & 100 \\
\hline
\end{tabular}

Source: Primary data processed, 2016

Based on data from table 1, it is known that the most respondents were female, namely 59 people $(60.8 \%)$. The majority of respondents 
have an age range of 40-59 years as many as 59 people $(60.8 \%)$. The highest level of education among respondents was junior high, which was 55 people $(56.7 \%)$. The majority of respondents work as farmers, as many as 44 people $(45.4 \%)$. The majority of relationships with patients are relationships with children, as many as 38 people $(39.2 \%)$.

\section{2). Family Perceptions of Nurses}

In the family's perception of nurses used to determine the positive and negative results of respondents.

Table 2. Family Perceptions of Nurses with Readiness in Receiving Discharge (n=97)

\begin{tabular}{lll}
\hline Perception & $\begin{array}{l}\text { Frek } \\
\text { (n) }\end{array}$ & Persentase (\%) \\
\hline Positif & 71 & 73,2 \\
Negatif & 26 & 26,8 \\
\hline Total & $\mathbf{9 7}$ & $\mathbf{1 0 0 , 0}$ \\
\hline
\end{tabular}

Source: Primary data processed, 2016.

Based on table 2 it is known that the majority of family perceptions of nurses in the positive category is 71 people $(73.2 \%)$.

\section{3). Family Readiness in Receiving Discharge Planning.}

In family readiness in receiving discharge planning is used to determine whether the readiness is good, sufficient, or lacking in respondents.

Table 3. Frequency Distribution of Family Readiness in Receiving Discharge Planning in Bantul Yogyakarta 2016.

\begin{tabular}{lll}
$\begin{array}{l}\text { Readiness to } \\
\text { accept }\end{array}$ & $\begin{array}{l}\text { Frek } \\
\text { (n) }\end{array}$ & Persentase (\%) \\
Discharge & & \\
Planning & & \\
\hline
\end{tabular}

\begin{tabular}{lll}
\hline Good & 52 & 53,6 \\
enough & 32 & 33,0 \\
less & 13 & 13,4 \\
\hline Total & $\mathbf{9 7}$ & $\mathbf{1 0 0 , 0}$ \\
\hline
\end{tabular}

Source: Primary data processed, 2016

Based on table 3 it is known that the majority of family readiness in accepting discharge planning falls into the good category of 52 people $(53.6 \%)$.

\section{b. Bivariate Results}

Table 4. The Relationships Between Family Perceptions of Nurses and Readiness in Receiving Discharge Planning ( $\mathbf{n = 9 7 )}$

\begin{tabular}{lllllllll}
\hline Perception & \multicolumn{3}{l}{ Readiness } & & \multicolumn{3}{c}{ p- } \\
from & \multicolumn{2}{l}{ Good } & Enough & \multicolumn{2}{l}{ Less } & Value \\
\cline { 2 - 7 } family & $\mathrm{f}$ & $\%$ & $\mathrm{f}$ & $\%$ & $\mathrm{f}$ & $\%$ & & \\
\hline Positif & 50 & 70,4 & 20 & 28,2 & 1 & 1,4 & & 0 \\
Negatif & 2 & 7,7 & 12 & 46,2 & 12 & 46,2 & & 0,00 \\
\hline Total & 52 & 54 & 32 & 33,0 & 13 & 13 & & \\
\hline
\end{tabular}

Source: Primary data processed, 2016.

Based on Table 4, it is known that of 71 respondents (73.2\%) whose family perceptions of nurses with the positive category the majority were in readiness to receive good charge planning, as many as 50 respondents (70.4\%). The majority of family perceptions about nurses with a negative category are in readiness in accepting less planning planning as many as 12 respondents (46.2\%).

Statistical results using the Spearman Rank test showed p-value 0.00 <alpha 0.01 meaning that $\mathrm{H} 0$ was rejected and $\mathrm{Ha}$ was accepted, namely the relationship between family perceptions of nurses and readiness to receive discharge planning at Panembahan Senopati Hospital in Bantul, Yogyakarta. Coefficient Correlation level (r) 0.641 shows that there is a close relationship between family perceptions about nurses and readiness to accept discharge planning. 


\section{DISCUSSIONS}

\section{a. Family Perceptions of Nurses}

Based on table 2: Regarding the assessment of the family of nurses in the positive category, 71 respondents $(73.2 \%)$. this shows the family's trust in the nurse and for what was done, so that the compilation of patients will go home then the family is ready to support and help patients compile home. Results Family perceptions in this study are very good, it only needs to be reviewed about how nurses provide better information to patients and their families need to compile patients to go home they can give what has been given by nurses in the hospital.

Based on the analysis of the frequency distribution of most respondents (family) in this study had a good perception of nurses in discharge planning to patients. The role of nurses in the provision of discharge planning in patients who are suffering from illness must be more optimal in order to accelerate the patient's recovery. In the process of discharge planning not only involves the patient but also the family and close friends or people around the patient in order to achieve ongoing coordination of care from the hospital.

The results of this study indicate that the distribution of experimental respondent characteristics by age is that the most aged 40-59 years are 59 respondents $(60.8 \%)$, and the least is the age of 21-39 years as many as 38 respondents $(39.2 \%)$. enough age, maturity level and strength of a person will be more mature in working and thinking (Nursalam, 2002). The more old enough someone will have more experience and more mature thinking skills. The perception of a person or group can be very different from the perception of other people or groups even though the situation is the same. Differences in perception can be traced to differences in personality, differences in attitudes or differences in motivation. Basically the process of formation of this perception occurs in a person, but perception is also influenced by experience, learning process, and knowledge.

The education level of the respondents in this study included having less education levels. This can be seen from the distribution of characteristics of experimental respondents based on education at most, namely SMP with 55 respondents $(56.7 \%)$ and at least D3 with 3 respondents $(3.1 \%)$. Knowledge is obtained from a person through the learning process, so that the higher the education will make the knowledge about an object the better it will form a better perception (Notoadmojo, 2010).

The types of work of respondents in this study were mostly in the experimental group as farmers 44 respondents $(45.4 \%)$ and the least were civil servants as many as 4 respondents (4.1\%). Work also affects the level of knowledge. This can be seen in table 1 that most respondents are farmers. This allows the farmers to get less knowledge about health. High knowledge can be obtained through the facts (facts) by seeing or hearing yourself through communication tools such as newspapers, television, radio, etc (Arikunto, 2002).

Based on the question items from the questionnaire distributed to families stating that nurses explain about the patient's illness, nurses explain the time and how to take medication, nurses explain about activities that can and should not be done by patients, nurses always communicate with patients / families when they will take action, nurses also provide information clearly to patients / families, nurses create a comfortable atmosphere for patients / families, nurses provide advice for patient recovery, nurses provide advice on other alternative therapies to patients / families, nurses explain every action to be taken to patients / family, nurses provide motivation to patients, nurses also provide advice on therapy and treatment.

Nursing staff at Panembahan Senopati Hospital Bantul Yogyakarta in taking action as a discharge planning nurse examines each patient 
by collecting and using related data to identify actual and potential problems, determine goals with or with patients and families, provide special measures to teach and study individually in maintaining or recovering the patient's condition optimally and evaluating continuity. Nursing care is carried out to prevent and improve the health condition of the patient, and as a member of the health team, nurses collaborate with other teams to plan, take action, coordinate and facilitate total care and also help patients achieve their main goal in improving their health status.

\section{b. Family Readiness in Receiving Discharge Planning}

The results of the frequency distribution of readiness in receiving discharge planning show that the majority of families have a good category readiness with a family number of 52 or $(53.6 \%)$. Based on the results of the analysis of the frequency distribution of some families have a good level of readiness seen from the results of observations made to the family of most families will prevent things that can cause recurrence of the patient's disease, practice how to treat patients according to what has been taught by nurses, supervise the food consumed patients at home, supervising patients in terms of taking medication, helping patients move that can accelerate healing, creating a comfortable atmosphere at home for the healing of patients, giving praise when patients do positive things for healing, always providing motivation (S.upriyati, 2008)

Based on the results of research conducted by researchers, the family's perception of nurses with readiness to receive discharge planning is positive (73.2\%). Collaboration between nurses who are on duty in the inpatient room with the family who are waiting for patients in the hospital, where nurses provide health education such as activities that may or may not be done by the patient, explaining how to treat patients to the family, food that may be and may not be consumed by patients, and so on. Modifications are also made by the family with nurses to facilitate and meet patient needs in terms of caring for patients. Nurses can provide information to the patient's family about better health education so that the patient's recovery is more optimal. Support and family assistance is still very much needed by patients in the healing process.

Readiness is a competency means that someone who has competence means that someone has enough readiness to do something. In conditions where if one family suffers illness, the family must be better prepared to deal with a sick family in terms of recognizing the health development disorder of each family member, making the decision to take the right action, before the family can make the right decision regarding the problem. health experienced, the nurse must be able to assess the family's situation in order to facilitate the family in making decisions, provide care to family members who are sick, and who can not help themselves because of disabilities or age that is too old, maintain a favorable home atmosphere for health and the personal development of family members, maintaining mutual relations between family members and health facilities ${ }^{11}$.

In the characteristics of respondents the age factor greatly influences the family's readiness to accept discharge planning that the higher the age the lower the physical condition experienced by the family in caring for a sick family ${ }^{13}$, it can be seen from the table that some respondents have an age range of 40-59 years ie as many 59 people $(60.8 \%)$. Congnitive functions include learning processes, perceptions of understanding, understanding, attention and others that cause reactions and behavior of the elderly to be increasingly slow. Psychomotor functions are things related to impulse like movements, actions, coordination which results in the elderly being less deft. The level of education also influences the family's readiness to 
accept discharge planning that the lower the level of education the lower the family's readiness in caring for sick family members ${ }^{2}$. It can be seen from the table that the highest level of education in respondents was junior high, which was 55 people $(56.7 \%)$.

The results showed there were still families of patients with a lack of readiness $(13.4 \%)$. Knowledge about the importance of preparedness is still not mastered by the family due to several factors including physical condition, needs or motives and goals, knowledge and skills.

\section{c. Relationship of Family Perception with Discharge Planning}

The family's perception of a good discharge planning can run a good discharge planning in patients. There is a relationship between family perceptions with discharge planning in Bantul Yogyakarta.

The family is a basic unit in society that has a great influence on family members because the patient's family is the most important resource in providing health services for the healing and comfort of the patient because there is a strong attachment between the family and the health status of its members. When viewed from the perspective of the community, the family is also a basic system where health and care behavior is regulated, carried out and carried out, the family provides health promotion and preventive health care for sick family members, so that the family's role in the sick family member is important to be involved in achieving optimum health. That is the reason why the role of the family in sick family members is important ${ }^{15}$.

Based on the questionnaire distributed, it is known that the family's perception of nurses in the positive category in dealing with sick family members has good knowledge in discharge planning, because while in the hospital they realize as a party of the patient's family that has the role that is expected to be done to improve the optimization of healing, because they is part of the treatment and patient care team. This is in accordance with the results of research Supriyati (2008) which says the need for the function of the family in the care of patients in the hospital or when going home.

The nurse will explain the illness suffered by the patient and explain how the family can help treat the patient after the patient is discharged from the hospital. In addition, the nurse also explained about food that might and might not be done by the patient that could not be done by the patient himself because the nurse was the care and treatment team in the hospital ward. In caring for patients, there needs to be a close relationship between family perceptions about care and planning for the return of the inpatient ward at the hospital.

\section{CONCLUSIONS}

Most families in this study had positive perceptions and good support about the readiness to accept patient discharge planning. The majority of patients' families have readiness in either category. There is a relationship between families in accepting the planning of patients going home with the perception of nurses by families in Panembahan Senopati Hospital Bantul Yogyakarta.

For Panembahan Senopati Hospital Bantul Yogyakarta It is hoped to further enhance the role of nurses in providing health care to families, especially in discharge planning in order to optimize the healing of patients.

For nursing staff, it is expected to be able to improve nursing performance in the provision of health services or better information and involve families in their actions as a form of collaboration.

For future researchers, the results of this study are expected to be a source of basic information for future research on family perceptions about nurses with readiness to accept 
discharge planning, especially in the fields of nursing and other health.

Acknowledgments to colleagues at the Bantul regional hospital and the PPNI commissioner of the Respati University who contributed to the study.

\section{REFERENCES}

Notoatmojo. 2003. Pendidikan Dan Perilaku Kesehatan. Jakarta: PT. Rineka Cipta.

2010. Metode Penelitian

Kesehatan. Ed. Rev. Jakarta : Rineka Cipta.

Gaffar 2014, Pengantar Keperawatan Profesional. Jakarta: EGC

Keeling, A.W. dan Ramos, M.C. (2008) Nurs Health Care: Perspectives on Community. The role of nursing history in preparing nursing for the future.

Suliswati (2005). Konsep Dasar Keperawatan Jiwa. Jakarta:EGC.

Kozier Barbara dkk, Alih Bahasa Devi Yulianti dkk. Fundamental Keperawatan.Ed 7. Jakarta: Pener bit Buku Kedokteran EGC; 2011.

Pemila, Uke (2009). Konsep Discharge Planning. Diambil pada tanggal 7 Februari 2014 dari http:152.118.148.220/ pkko/ fikes/ konsep\%,20 DISCHARGE\% PLANNING.doc.

Ester, M. (2005). Pedoman Perawatan Pasien. Jakarta:EGC.

Nursalam. (2002) Manajemen Keperawatan: Aplikasi dalam praktek keperawatan. Jakarta: Salemba Medika.
Arikunto, S. 2002. Prosedur Penelitian Suatu Pendekatan Praktek. Jakarta: Rineka Cipta.

Yusnawati. 2007. Kesiapan berwirausaha siswa jurusan kecantikan SMKN. Skripsi Yogyakarta: FT UNY.

Judha, Mohamad. 2017. Pengetahuan, Pendidikan Dan Status Ekonomi Berhubungan Dengan Ketaatan Kontrol Gula Darah Pada Penderita DM Di Rsup Dr Soeradji Tirtonegoro Klaten. http://medika.respati.ac.id/index.php/Me dika/article/view/32 Yogyakarta : Jurnal Medika Respati 2016. Pekerja Pengalaman Care Dalam Memenuhi Kebutuhan Dasar Retardasi Mental Di Panti Asuhan. http://nursingjurnal.respati.ac.id/index.p hp/JKRY/article/view/134 Yogyakarta : Jurnal Keperawatan Respati Yogyakarta. Watson, J. Nursing: Human Science and Human Care: a Theory of Nursing. Jones \& Bartlett Learning; 1999 ., Foster, R. (2003). The Attending Nurse Caring Model®: integrating theory, evidence and advanced caringhealing therapeutics for transforming professional practice. Journal of clinical nursing; $2003: 360-365$.

Supriyati, (2008). Hubungan tingkat pengetahuan dengan sikap perawat dalam aplikasi pencegahan ansietas penderita pre operatif elektif di Rumah sakit Orthopedi Prof. Dr.R Soeharso Surakarta, penelitian, http://etd.eprints.ums.ac.id/439/ retritive 17 Juni 2017. 